Original Research Paper

\title{
Aplikasi Pupuk Organik dan NPK untuk Meningkatkan Pertumbuhan Vegetatif dan Produksi Buah Terong Hijau
}

\author{
Ahmad Raksun $^{1 *}$, Lalu Japa ${ }^{1}$, I Gde Mertha ${ }^{1}$ \\ ${ }^{1}$ Program Studi Pendidikan Biologi Fakultas Keguruan dan Ilmu Pendidikan Universitas Mataram, Indonesia
}

\author{
Article history \\ Received: December $1^{\text {th }} 2018$ \\ Revised: April $22^{\text {th }} 2019$ \\ Accepted: May $9^{\text {th }} 2019$ \\ *Ahmad Raksun: Program \\ Studi Pendidikan Biologi \\ Fakultas Keguruan dan Ilmu \\ Pendidikan Universitas \\ Mataram, Indonesia; \\ Email: \\ ahmadunram@unram.ac.id
}

\begin{abstract}
Research has been conducted on the application of organic and NPK fertilizer to increase the growth and yield of green eggplant which aims to find out (1) the influence of organic fertilizer on vegetative growth and yield of Green eggplant, (2) the effect of NPK fertilizer on vegetative growth and yield of Green Eggplant, (3) the effect of interaction between organic fertilizer and NPK fertilizer on vegetative growth and yield of Green Eggplant. A Factorial design was used which consisted of 2 factors. The first factor is the dose of organic fertilizer and the second factor is the dose of NPK fertilizer. The treatment of organic fertilizer consists of 4 levels, namely: $\mathrm{P} 0=$ without giving organic fertilizer $($ control), $\mathrm{P} 1=$ giving $0.5 \mathrm{~kg}$ organic fertilizer $/ 1 \mathrm{~m} 2$ land, $\mathrm{P} 2$ = giving $1.0 \mathrm{~kg}$ organic fertilizer $/ 1 \mathrm{~m} 2$ land, $\mathrm{P} 3=$ giving $1.5 \mathrm{~kg}$ organic fertilizer/1 $\mathrm{m} 2$ land. NPK fertilizer consists of 5 levels namely: N0 = without NPK fertilizer (control), N1 = giving 5 gr NPK fertilizer/plant, P2 = giving 10 gr NPK fertilizer/plant, P3 = giving 15 gr NPK fertilizer/plant, P4 = giving 20 gr NPK fertilizer/plant. Growth parameters were stem height and length of green eggplant leaves. Yield parameters were fruit length and green eggplant fruit weight. Data were analyzed by using ANOVA. The results showed that the application of organic fertilizer has a significant effect on the growth and yield of green eggplant. The application of NPK fertilizer has a significant effect on the growth and yield of green eggplant. The interaction of organic fertilizer and NPK fertilizer did not significantly affect the growth and yield of green eggplant.
\end{abstract}

Key Words: organic fertilizer; NPK fertilizer; growth and production of green eggplant.

Abstrak: Telah dilakukan penelitian tentang aplikasi pupuk organik dan pupuk NPK untuk meningkatkan pertumbuhan dan produksi terong hijau yang bertujuan untuk mengetahui (1) pengaruh pupuk organik terhadap pertumbuhan vegetatif dan produksi buah Terong Hijau, (2)pengaruh pupuk NPK terhadap pertumbuhan vegetatif dan produksi buah Terong Hijau, (3)pengaruh interaksi pupuk organik dan pupuk NPK terhadap pertumbuhan vegetatif dan produksi buah Terong Hijau. Penelitian ini menggunakan rancangan Faktorial yang terdiri atas 2 faktor. Faktor pertama adalah dosis pupuk organik dan faktor kedua adalah dosis pupuk NPK. Perlakuan pupuk organik terdiri atas 4 level yaitu: $P_{o}=$ tampa pemberian pupukorganik (kontrol), $\mathrm{P}_{1}=$ pemberian $0,5 \mathrm{~kg}$ pupuk organik $/ 1 \mathrm{~m}^{2}$ lahan, $\mathrm{P}_{2}=$ pemberian $1,0 \mathrm{~kg}$ pupuk organik $/ 1 \mathrm{~m}^{2}$ lahan, $\mathrm{P}_{3}=$ pemberian $1,5 \mathrm{~kg}$ pupuk organik/1 $\mathrm{m}^{2}$ lahan, Selanjutnya faktor pupuk NPK terdiri atas 5 level yaituN $\mathrm{N}_{0}=$ tampa pemberian pupuk NPK (kontrol), $\mathrm{N}_{1}=$ pemberian 5 gramNPK/tanaman, $\mathrm{P}_{2}=$ pemberian 10 grampupuk NPK/tanaman, $\mathrm{P}_{3}=$ pemberian 15 grampupuk $\mathrm{NPK} /$ tanaman, $\mathrm{P}_{4}=$ pemberian 20 gr pupuk NPK/tanaman. Parameter pertumbuhan yang diukur adalahtinggi batang dan panjang daun terong hijau.Parameter produksi yang diukur adalah panjang buah dan berat basah buah terong hijau. Data dianalisis dengan analisis sidik ragam. Hasil penelitian menunjukkan bahwa aplikasi pupuk organik berpengaruh nyata terhadap pertumbuhan dan produksi buah terong hijau. 
Aplikasi pupuk NPK berpengaruh nyata terhadap pertumbuhan dan produksi buah terong hijau. Interaksi pupuk organik dan pupuk NPK tidak berpengaruh nyata terhadap pertumbuhan dan produksi buah terong hijau

Kata Kunci: Pupuk organic; pupuk NPK; pertumbuhan dan produksi buah terong hijau.

\section{Pendahuluan}

Pertumbuhan dan produksi tanaman sangat ditentukan oleh ketersediaan unsur hara pada lahan pertanian. Upaya meningkatkan ketersediaan unsur hara pada lahan pertanian dapat dilakukan dengan pemupukan, Pemupukan tanaman dapat dilakukan dengan mengguakan pupuk kimia maupun pupuk organik. Pemupukan dengan pupuk kimia tampa ada pemberian bahan organik pada lahan pertanian pada kenyataannya menyebabkan kebutuhan pupuk kimia per hektar lahan cendung meningkat. Untuk mengurangi penggunaan pupuk kimia, maka salah satu cara yang dapat dilakukan adalah mengkombinasikan pupuk kimia dan pupuk organik.

Pupuk organik adalah pupuk yang dibuat dengan bahan baku sampah organik. Pemberian pupuk organik pada lahan pertanian sangat penting dalam menjaga kesuburan tanah dan pertumbuhan tanaman. Musnamar (2003) menjelaskan bahwa pemberian pupuk organik dapat memperbaiki sifat fisik, kimia dan biologi tanah. Sifat fisik, kimia dan biologi tanah yang baik berpengaruh positif terhadap pertumbuhan dan produksi tanaman.

Berbagai hasil penelitian menunjukkan bahwa aplikasi pupuk organik pada lahan pertanian berdampak positif terhadap pertubuhan dan produksi tanaman. Penggunaan pupuk organik berpengaruh nyata terhadap parameter tinggi batang tanaman, diameter batang, indeks luas daun, panjang tongkol dan bobot segar tongkol per hektar tanaman jagung manis (Nurcahya dkk, 2017). Pemberian pupuk organik cair dapat meningkatkan pertumbuhan kedelai (Raksun, 2014).Pemberian pupuk organik dapat meningkatkan pertumbuhan bibit jambu mete (Raksun, 2016).Perlakuan perendaman bibit rumput laut dalam larutan pupuk organik cair memberikan dampak positif terhadap pertumbuhan bibit rumput laut Euchema cottonii (Karnan dkk, 2015). Sejauh ini belum ada laporan hasil penekitian tentang pengaruh pupuk organik dan pupuk NPK terhadap pertumbuhan dan produksi tanaman terong hijau.
Berdasarkan uraian di atas maka peneliti melakukan penelitian tentang pengaruh pupuk organik dan pupuk NPK terhadap pertumbuhan vegetatif dan produksi buah terong hijau. Adapun tujuan dilaksanakannya penelitian ini adalah untuk mengetahui: (1) pengaruh pupuk organik terhadap pertumbuhan vegetatif dan produksi buah terong hijau, (2) pengaruh pupuk NPK terhadap pertumbuhan vegetatif dan produksi buah terong hijau, (3 pengaruh interaksi pupuk organik dan pupuk NPK terhadap pertumbuhan vegetatif dan produksi buah terong hijau.

\section{Metode dan Bahan}

Penelitian ini telah dilaksanakan mulai bulan Juni sampai dengan Nopember 2018 di Desa Sukarara Kecamatan Jonggat Kabupaten Lombok Tengah Bahan-bahan yang digunakan dalam penelitian ini adalah kertas label, bahan-bahan pembuatan rumah kaca sederhana (bambu, tali rapia, besi paku dan kertas transparan), benih terong hijau, air, pupuk organik, pupuk NPK, insektisida, mulsa plastik dan fungisida. Selanjutnya alat yang digunakan adalah artco dorong, ember plastik, pot plastik, parang, palu, cangkul, timbangan, alat tulis menulis, gunting, karung goni,karung nilon, terpal, mesin pompa air, meteran, sekop dan hand sprayer.

Rancangan Faktorial yang terdiri atas 2 faktor telah digunakan dalam peneelitian ini. Faktor pertama adalah dosis pupuk organik dan faktor kedua adalah dosis pupuk NPK. Dosis pupuk organik terdiri atas 4 level yaitu: $\mathrm{P}_{0}=$ tampa pemberian pupuk organik (kontrol), $\mathrm{P}_{1}=$ pemberian $0,5 \mathrm{~kg}$ pupuk organik $/ 1 \mathrm{~m}^{2}$ lahan, $\mathrm{P}_{2}=$ pemberian $1,0 \mathrm{~kg}$ pupuk organik $/ 1 \mathrm{~m}^{2}$ lahan, $\mathrm{P}_{3}=$ pemberian $1,5 \mathrm{~kg}$ pupuk organik/1 $\mathrm{m}^{2}$ lahan. Selanjutnya faktor pupuk NPK terdiri atas 5 level yaituN $N_{0}=$ tampa pemberian pupuk NPK, $\mathrm{N}_{1}=$ pemberian 5 gram pupuk NPK/tanaman, $\mathrm{N}_{2}=$ pemberian 10 gram pupukNPK/tanaman, $\mathrm{N}_{3}=$ 
pemberian 15 gram pupukNPK/tanaman, $\mathrm{N}_{4}=$ pemberian 20 gram pupukNPK/tanaman.

Parameter pertumbuhan yang diukur adalah tinggi batang dan panjang daun terong hijau umur 60 hari setelah tanam.Selanjutnya parameter produksi yang diukur adalah panjang buah dan berat basah buah terong hijau. Data kuantitatif hasi pengukuran parameter di atas dianalisis dengan analisis sidik ragam (Toutenburg and Shalabh, 2009)

\section{Hasil dan Pembahasan}

Data hasil pengukuran parameter pertumbuhan dan parameter produksi tanaman terung hijau adalah sebagai berikut:

Tabel 1. Rerata Tinggi Batang Terung Hijau Akibat Perlakuan Pupuk Organik dan NPK

\begin{tabular}{llll}
\hline $\begin{array}{l}\text { Perla- } \\
\text { kuan }\end{array}$ & $\begin{array}{l}\text { Rerata tinggi } \\
\text { batang }(\mathrm{cm})\end{array}$ & $\begin{array}{l}\text { Perla- } \\
\text { kuan }\end{array}$ & $\begin{array}{l}\text { Rerata tinggi } \\
\text { batang }(\mathrm{cm})\end{array}$ \\
\hline $\mathrm{P}_{0} \mathrm{~N}_{0}$ & 43 & $\mathrm{P}_{2} \mathrm{~N}_{0}$ & 48 \\
$\mathrm{P}_{0} \mathrm{~N}_{1}$ & 46 & $\mathrm{P}_{2} \mathrm{~N}_{1}$ & 53 \\
$\mathrm{P}_{0} \mathrm{~N}_{2}$ & 49 & $\mathrm{P}_{2} \mathrm{~N}_{2}$ & 56 \\
$\mathrm{P}_{0} \mathrm{~N}_{3}$ & 52 & $\mathrm{P}_{2} \mathrm{~N}_{3}$ & 59 \\
$\mathrm{P}_{0} \mathrm{~N}_{4}$ & 45 & $\mathrm{P}_{2} \mathrm{~N}_{4}$ & 57 \\
$\mathrm{P}_{1} \mathrm{~N}_{0}$ & 46 & $\mathrm{P}_{3} \mathrm{~N}_{0}$ & 52 \\
$\mathrm{P}_{1} \mathrm{~N}_{1}$ & 48 & $\mathrm{P}_{3} \mathrm{~N}_{1}$ & 54 \\
$\mathrm{P}_{1} \mathrm{~N}_{2}$ & 50 & $\mathrm{P}_{3} \mathrm{~N}_{2}$ & 58 \\
$\mathrm{P}_{1} \mathrm{~N}_{3}$ & 52 & $\mathrm{P}_{3} \mathrm{~N}_{3}$ & 64 \\
$\mathrm{P}_{1} \mathrm{~N}_{4}$ & 47 & $\mathrm{P}_{3} \mathrm{~N}_{4}$ & 61 \\
\hline
\end{tabular}

Data pada Tabel 1 menunjukkan bahwa rerata tinggi batang terong hijau tertinggi adalah 64 $\mathrm{cm}$ terdapat pada perlakuan $\mathrm{P}_{3} \mathrm{~N}_{3}$ (perlakuan $1,5 \mathrm{~kg}$ pupuk organik per $1 \mathrm{~m}^{2}$ lahan yang dikombinasikan dg 15 gram pupuk NPK per tanaman). Selanjutnya hasil analisis sidik ragam menunjukkan bahwa pemberian pupuk organik berpengaruh sangat nyata terhadap tinggi batang terong hijau, perlakauan pupuk NPK berpengaruh sangat nyata terhadap tinggi batang terong hijau, interaksi pupuk organik dan pupuk NPK tidak berpengaruh nyata terhadap tinggi batang terung hijau.Selanjutnya data hasil pengukuran panjang daun terong hijau terdapat pada tabel berikut.

Tabel 2. Rerata Panjang daun Terung Hijau Akibat Perlakuan Pupuk Organik dan NPK

\begin{tabular}{llll}
\hline $\begin{array}{l}\text { Perla- } \\
\text { kuan }\end{array}$ & $\begin{array}{l}\text { Rerata panjang } \\
\text { daun }(\mathrm{cm})\end{array}$ & $\begin{array}{l}\text { Perl- } \\
\text { akuan }\end{array}$ & $\begin{array}{l}\text { Rerata panjang } \\
\text { daun }(\mathrm{cm})\end{array}$ \\
\hline $\mathrm{P}_{0} \mathrm{~N}_{0}$ & 22 & $\mathrm{P}_{2} \mathrm{~N}_{0}$ & 24 \\
$\mathrm{P}_{0} \mathrm{~N}_{1}$ & 23 & $\mathrm{P}_{2} \mathrm{~N}_{1}$ & 25 \\
$\mathrm{P}_{0} \mathrm{~N}_{2}$ & 24 & $\mathrm{P}_{2} \mathrm{~N}_{2}$ & 26 \\
$\mathrm{P}_{0} \mathrm{~N}_{3}$ & 25 & $\mathrm{P}_{2} \mathrm{~N}_{3}$ & 28 \\
$\mathrm{P}_{0} \mathrm{~N}_{4}$ & 24 & $\mathrm{P}_{2} \mathrm{~N}_{4}$ & 26 \\
$\mathrm{P}_{1} \mathrm{~N}_{0}$ & 23 & $\mathrm{P}_{3} \mathrm{~N}_{0}$ & 24 \\
\hline
\end{tabular}

\begin{tabular}{llll}
\hline $\begin{array}{l}\text { Perla- } \\
\text { kuan }\end{array}$ & $\begin{array}{l}\text { Rerata panjang } \\
\text { daun }(\mathrm{cm})\end{array}$ & $\begin{array}{l}\text { Perl- } \\
\text { akuan }\end{array}$ & $\begin{array}{l}\text { Rerata panjang } \\
\text { daun }(\mathrm{cm})\end{array}$ \\
\hline $\mathrm{P}_{1} \mathrm{~N}_{1}$ & 24 & $\mathrm{P}_{3} \mathrm{~N}_{1}$ & 26 \\
$\mathrm{P}_{1} \mathrm{~N}_{2}$ & 25 & $\mathrm{P}_{3} \mathrm{~N}_{2}$ & 27 \\
$\mathrm{P}_{1} \mathrm{~N}_{3}$ & 26 & $\mathrm{P}_{3} \mathrm{~N}_{3}$ & 29 \\
$\mathrm{P}_{1} \mathrm{~N}_{4}$ & 25 & $\mathrm{P}_{3} \mathrm{~N}_{4}$ & 29 \\
\hline
\end{tabular}

Rerata panjang daun terung hijau tertinggi adalah $29 \mathrm{~cm}$ terdapat pada perlakuan $\mathrm{P}_{3} \mathrm{~N}_{3}$ dan pada perlakuan $\mathrm{P}_{3} \mathrm{~N}_{4}$ (perlakuan $1,5 \mathrm{~kg}$ pupuk organik per $1 \mathrm{~m}^{2}$ lahan yang dikombinasikan dg 15 gram dan 20 gram pupuk NPK per tanaman. Hasil analisis sidik ragam menunjukkan bahwa perlakuan pupuk organik berpengaruh sangat nyata terhadap panjang daun terong hijau, perlakauan pupuk NPK berpengaruh sangat nyata terhadap panjang daun terong hijau, interaksi pupuk organik dan pupuk NPK tidak berpengaruh nyata terhadap panjang daun terung hijau. Selanjutnya data hasil pengukuran panjang buah terung hijau terdapat pada tabel 3 .

Tabel 3. Rerata Panjang Buah Terung Hijau Akibat Perlakuan Pupuk Organik dan NPK

\begin{tabular}{llll}
\hline $\begin{array}{l}\text { Perla- } \\
\text { kuan }\end{array}$ & $\begin{array}{l}\text { Rerata panjang } \\
\text { buah }(\mathrm{cm})\end{array}$ & $\begin{array}{l}\text { Perla- } \\
\text { kuan }\end{array}$ & $\begin{array}{l}\text { Rerata panjang } \\
\text { buah }(\mathrm{cm})\end{array}$ \\
\hline $\mathrm{P}_{0} \mathrm{~N}_{0}$ & 18 & $\mathrm{P}_{2} \mathrm{~N}_{0}$ & 24 \\
$\mathrm{P}_{0} \mathrm{~N}_{1}$ & 20 & $\mathrm{P}_{2} \mathrm{~N}_{1}$ & 25 \\
$\mathrm{P}_{0} \mathrm{~N}_{2}$ & 22 & $\mathrm{P}_{2} \mathrm{~N}_{2}$ & 25 \\
$\mathrm{P}_{0} \mathrm{~N}_{3}$ & 24 & $\mathrm{P}_{2} \mathrm{~N}_{3}$ & 26 \\
$\mathrm{P}_{0} \mathrm{~N}_{4}$ & 22 & $\mathrm{P}_{2} \mathrm{~N}_{4}$ & 25 \\
$\mathrm{P}_{1} \mathrm{~N}_{0}$ & 22 & $\mathrm{P}_{3} \mathrm{~N}_{0}$ & 25 \\
$\mathrm{P}_{1} \mathrm{~N}_{1}$ & 23 & $\mathrm{P}_{3} \mathrm{~N}_{1}$ & 26 \\
$\mathrm{P}_{1} \mathrm{~N}_{2}$ & 24 & $\mathrm{P}_{3} \mathrm{~N}_{2}$ & 27 \\
$\mathrm{P}_{1} \mathrm{~N}_{3}$ & 26 & $\mathrm{P}_{3} \mathrm{~N}_{3}$ & 29 \\
$\mathrm{P}_{1} \mathrm{~N}_{4}$ & 24 & $\mathrm{P}_{3} \mathrm{~N}_{4}$ & 28 \\
\hline
\end{tabular}

Data pada Tabel 3. menunjukkan bahwa rerata panjang buah terung hijau tertinggi adalah 29 cm terdapat pada perlakuan $\mathrm{P}_{3} \mathrm{~N}_{3}$ (perlakuan $1,5 \mathrm{~kg}$ pupuk organik per $1 \mathrm{~m}^{2}$ lahan yang dikombinasikan dengan 15 gram pupuk NPK per tanaman). Hasil analisis sidik ragam menunjukkan bahwa perlakuan pupuk organik bepengaruh sangat nyata terhadap panjang buah terong hijau. Perlakuan pupuk NPK berpengaruh sangat nyata terhadap panjang buah terung hijau. Interaksi pupuk organik dan pupuk NPK tidak berpengaruh nyata terhadap panjang buah terung hijau.

Tabel 4. Rerata Berat Basah Buah Terung Hijau Akibat Perlakuan Pupuk Organik dan NPK

\begin{tabular}{llll}
\hline $\begin{array}{l}\text { Perla- } \\
\text { kuan }\end{array}$ & $\begin{array}{l}\text { Rerata berat } \\
\text { buah (gram) }\end{array}$ & $\begin{array}{l}\text { Perla- } \\
\text { kuan }\end{array}$ & $\begin{array}{l}\text { Rerata berat buah } \\
\text { (gram) }\end{array}$ \\
\hline $\mathrm{P}_{0} \mathrm{~N}_{0}$ & 545 & $\mathrm{P}_{2} \mathrm{~N}_{0}$ & 574 \\
$\mathrm{P}_{0} \mathrm{~N}_{1}$ & 565 & $\mathrm{P}_{2} \mathrm{~N}_{1}$ & 582 \\
$\mathrm{P}_{0} \mathrm{~N}_{2}$ & 573 & $\mathrm{P}_{2} \mathrm{~N}_{2}$ & 620 \\
$\mathrm{P}_{0} \mathrm{~N}_{3}$ & 583 & $\mathrm{P}_{2} \mathrm{~N}_{3}$ & 628 \\
$\mathrm{P}_{0} \mathrm{~N}_{4}$ & 560 & $\mathrm{P}_{2} \mathrm{~N}_{4}$ & 583 \\
\hline
\end{tabular}




\begin{tabular}{llll}
\hline $\begin{array}{l}\text { Perla- } \\
\text { kuan }\end{array}$ & $\begin{array}{l}\text { Rerata berat } \\
\text { buah (gram) }\end{array}$ & $\begin{array}{l}\text { Perla- } \\
\text { kuan }\end{array}$ & $\begin{array}{l}\text { Rerata berat buah } \\
\text { (gram) }\end{array}$ \\
\hline $\mathrm{P}_{1} \mathrm{~N}_{0}$ & 568 & $\mathrm{P}_{3} \mathrm{~N}_{0}$ & 624 \\
$\mathrm{P}_{1} \mathrm{~N}_{1}$ & 580 & $\mathrm{P}_{3} \mathrm{~N}_{1}$ & 655 \\
$\mathrm{P}_{1} \mathrm{~N}_{2}$ & 585 & $\mathrm{P}_{3} \mathrm{~N}_{2}$ & 654 \\
$\mathrm{P}_{1} \mathrm{~N}_{3}$ & 602 & $\mathrm{P}_{3} \mathrm{~N}_{3}$ & 663 \\
$\mathrm{P}_{1} \mathrm{~N}_{4}$ & 580 & $\mathrm{P}_{3} \mathrm{~N}_{4}$ & 637 \\
\hline
\end{tabular}

Data pada tabel 4 menunjukkan bahwa berat basah buah terung hijau tertinggi adalah 663 gram terdapat pada perlakuan $\mathrm{P}_{3} \mathrm{~N}_{3}$ (kombinasi perlakuan $1,5 \mathrm{~kg}$ pupuk organik dan 15 gram pupuk NPK). Hasil analisis sidik ragam menunjukkan bahwa perlakuan pupuk organik dan perlakuan pupuk NPK berpengaruh sangat nyata terhadap berat basah buah terung hijau. Interaksi perlakuan pupuk organik dan pupuk NPK tidak berpengaruh nyata terhadap berat basah buah terung hijau.

Hasil analisis data menunjukkan bahwa aplikasi pupuk organik pada lahan pertanian berpengaruh sangat nyata terhadap semua parameter pertumbuhan terong hijau, berpengaruh sangat nyata terhadap hasil panen buah terung hijau. Adanya pengaruh sangat nyata perlakuan pupuk organik terhadap semua parameter pertumbuhan dan produksi disebabkan karena bahan organik yang ditambahkan ke dalam tanah mengalami degradasi menjadi berbagai macam unsur hara terutama unsur nitrogen dan fospor. Lingga dan Marsono (2013) menjelaskan bahwa unsur hara nitrogen merupakan komponen penyusun asam amino, protein dan pembentukan protoplasma sel yang dapat berfungsi dalam merangsang pertumbuhan tanaman. Fosfor berperan terhadap pembelahan sel pada titik tumbuh yang berpengaruh pada tinggi tanaman.

Hasil penelitian ini sejalan dengan hasil penelitian yang sudah dilakukan oleh peneliti lainnya. Hasil penelitian yang dilakukan oleh Darmanto (2004) menunjukkan bahwa pemberian pupuk organik bokasi pada lahan pertanian dapat meningkatkan ketersediaan hara nitrat, sulfat dan pertumbuhan kacang panjang. Maruli dkk (2012) menyimpulkan bahwa pemberian pupuk organik kompos berpengaruh nyata terhadap tinggi tanaman, umur berbunga, umur panen dan berat buah cabai rawit. Aplikasi beberapa pupuk organik pada tanaman caisim (Brassica campestris var. chinensis L) dapat meningkatkan tinggi batang, panjang daun, lebar dan berat basah daun (Abuyamin 2016). Terdapat interaksi antara pupuk organik bokashi dan pupuk nitrogen terhadap jumlah daun, pemberian pupuk organik bokashi 10 ton/ha berpengaruh baik terhadap komponen kualitas bunga yaitu mampu menghasilkan tangkai bunga terpanjang dan jumlah kuntum bunga terbanyak (Farida dan Hamdani, 2003). Perlakuan pupuk organik kotoran ayam 15 ton per hektar dalam larikan mampu meningkatkan produksi jagung manis hingga 21,3\% dengan produksi yang mencapai 14,67 ton per hektar dibandingkan dengan pupuk anorganik (kontrol) (Rizqullah dkk, 2017). Pemberian pupuk organik kompos kotoran ayam bepengaruh nyata pada semua variabel pengamatan kecuali panjang tanaman bawang merah. Pemberian pupuk kandang ayam dosis 45 ton per hektar menghasilkan bobot segar total tanaman sebesar 2,93 ton per hektar pada kondisi penanaman di lahan dan pemberian kompos kotoran ayam dengan dosis yang sama menghasilkan bobot segar sebesat 2,10 ton per hektar pada kondisi penanaman di polybag (Rahman dkk, 2018).

Perlakuan pupuk NPK juga berpengaruh sangat nyata terhadap semua parameter yang diukur. Hal ini disebabkan karena unsur hara N, P dan $\mathrm{K}$ merupakan unsur hara makro bagi tumbuhan. Yousuf et al. (2014) melaporkan, bahwa tanaman coriander (Coriandrum sativum L.) menghasilkan produksi biji tertinggi $(2,06$ ton/ha pada tahun 2008-2009 dan 2,09 ton/ha pada tahun 2009-2010) diperoleh dari aplikasi moderat $\mathrm{N}, \mathrm{P}, \mathrm{K}$, dan $\mathrm{S}$ berturut-turut: $70,50,30$, dan $20 \mathrm{~kg} / \mathrm{ha}$, dan produksi menurun dengan dosis yang lebih tinggi unsur hara tersebut.Produksi biji tertinggi seperti itu terkait dengan jumlah maksimum cabang primer per tanaman $(8,65)$ tercatat pada penggunaan N70P50K30S20 kg/ha. Unsur hara N, P, K, dan S berperan secara nyata meningkatkan pertumbuhan dan perkembangan tanaman coriander, percabangan maksimum yang berimplikasi pada produksi biji yang melimpah. Tanaman coriander tertinggi $(74.20 \mathrm{~cm}$ dan $76.43 \mathrm{~cm})$ juga tercatat pada perlakuan (N70P50K30S20 kg/ha) dalam dua tahun berturut-turut 2008-2009 dan 2009-2010. Pemberian pupuk NPK mutiara berpengaruh nyata terhadap pertumbuhan dan produksi tanaman bawang merah. Perlakuan terbaik terdapat pada perlakuan $250 \mathrm{~g} /$ plot menghasilkan tinggi tanaman tertinggi $35,28 \mathrm{~cm}$, jumlah daun perumpun 11,67 helai, jumlah anakan perumpun 8,08 anakan, produksi per tanaman $46,35 \mathrm{~g}$ dan produksi per plot $1,17 \mathrm{~kg}$ (Efendi dkk, 2017). Tinggi tanaman, diameter batang, jumlah cabang produktif, jumlah daun, indeks luas daun, dan hasil panen tanaman terung memberikan respons positif terhadap aplikasi pupuk N,P,K (Firmansyah dkk, 2017). Pemberian pupuk NPK 142g (100\% dari dosis rekomendasi) meningkatkan panjang pelepah bibit 
pada umur 9 bulan, bobot keringt ajuk dan bobot kering akar bibit kelapa sawit di mainnursery.

Pemberian pupuk organic 36 gpolibeg $^{-1}$ meningkatkan tinggi tanaman, jumlah pelepah, diameter batang, dan $\mathrm{P}$ total bibit kelapa sawit di mainnursery. Terdapat interaksi antara pupuk NPK dan pupuk organik terhadap bobot kering akar bibit kelapa sawit di mainnursery. Interaksi terbaik terdapat pada perlakuan pemberian pupuk NPK $50 \%$ dan organic 36 gpolibeg $^{-1}$ (Adnan dkk, 2015)

\section{Kesimpulan}

Berdasarkan hasil analisis data dan pembahasan pada penelitian ini maka dapat disimpulkan bahwa (1) aplikasi pupuk organik berpengaruh sangat nyata terhadap pertumbuhan vegetatif dan produksibuah terong hijau, (2) aplikasi pupuk NPK berpengaruh nyata terhadap pertumbuhan vegetatif dan produksi buah terong hijau, (5) interaksi pupuk organik dan pupuk NPK tidak berpengaruh nyata terhadap pertumbuhan vegetatif dan produksi buah tanaman terong hijau, (7) dosis optimum pupuk organik untuk tanaman terong hijau adalah $1,5 \mathrm{~kg}$ pupuk organik per $1 \mathrm{~m}^{2}$ lahan, (9) dosis optimum pupuk NPK untuk tanaman terong hijau adalah 15 gram per tanaman.

\section{Ucapan Terimakasih}

Terimakasih yang sebesar-besarnya kami sampaikan kepada Rektor Universitas Mataram yang telah menyediakan dana penelitian. Terimakasih juga kami sampaikan kepada Ketua LPPM Universitas Mataram yang telah memfasilitasi pelaksanaan penelitian ini.

\section{Daftar Pustaka}

Abuyamin. 2016. Pengaruh Pemberian Urin Kelinci dan Kompos terhadap Pertumbuhan dan Hasil Tanaman Caisim (Brassica juncea L.). Plumula. Vol 5 (1) p. $69-79$

Adnan, I.S., B. Utoyo dan A. Kusumastuti. 2015. Pengaruh Pupuk NPK dan Pupuk Organik terhadap Pertumbuhan Bibit Kelapa Sawit (Elaeis guineensis Jacq.) di Main Nursery. AgroIndustri Perkebunan. Vol. 3(2): 69 81

Darmanto. 2004. Laporan Hasil Penelitian: Pengaruh Kadar Bokasi Terhadap
Ketersediaan Hara Nitrat, Sulfat dan Pertumbuhan Kacang Panjang. Universitas Gadjah Mada. Yogyakarta.

Efendi, E., D. W. Purba dan N.H.Nasution. 2017. Respon Pemberian Pupuk NPK Mutiara dan Bpkashi Jerami Padi terhadap Pertumbuhan dan Produksi Tanaman bawang Merah (AlliumascalonicumL). Penelitian Pertanian BERNAS Vol 13 (3): $20-30$

Farida dan J.S. Hamdani. 2003. Pertumbuhan dan Hasil Bunga Gladiol Pada Dosis Pupuk Organik Bokashi dan Nitrogen yang Berbeda. Bionatura V. 3(2) p. 68 - 76

Firmansyah, I., M. Syakirdan L. Lukman 2017. PengaruhKombinasiDosisPupukN,P,danKTe rhadap Pertumbuhandan Hasil Tanaman Terung (SolanummelongenaL.). J. Hort. Vol 7 (1): $69-78$

Karnan, A. Raksun dan L. Japa. 2015. Respon Pertumbuhan Rumput Laut Euchema cottonii terhadap Pemberian Pupuk Organik Cair di Teluk Ekas Lombok Timur. Biologi Tropis Vol 15 (1): 39 - 46

Knox, B., P. Ladiges, B. Evans. 1994. Biology. McGraw-Hill Book Company Australia Pty Limited. Australia.

Lingga, P. dan Marsono. 2013. Petunjuk Penggunaan Pupuk. Penebar Swadaya. Jakarta.

Maruli, Ernita dan H. Gultom. 2012. Pengaruh Pemberian NPK Grower dan Kompos terhadap Pertumbuhan dan Produksi Tanaman Cabai Rawit (Capsicum frustencen L.). Dinamika Pertanian. Vol XXVII (3) p. 149 - 155

Musnamar, E.I. 2003. Pupuk Organik Padat. Penebar Swadaya. Jakarta.

Nurcahya, A.O., N. Herlina dan B. Guritno. 2017. Pengaruh Macam Pupuk Organik dan Waktu Aplikasi terhadap Pertumbuhan dan Hasil Jagung Manis (Zea mays saccharata Sturt). Produsi Tanaman Vol 5 (9): 1476 1482

Raksun, A. 2014. Aplikasi Pupuk Organik Cair untuk Meningkatkan Pertumbuhan Kedelai (Glycine max L). Biologi Tropis Vol 14 (2): $62-67$

Raksun, A. 2016. Aplikasi Pupuk Organik untuk Meningkatkan Pertumbuhan Bibit Jambu Mete (Anacardium occidentale L). Biologi Tropis Vol 16 (2): 1 - 9

Rahman, A.S., A. Nugroho dan R. Soeslistyono. 2018. Kajian Hasil bawang Merah (Allium ascalonicum L) di Lahan dan Polybag 
dengan Pemberian Berbagai Macam Dosis Pupuk Organik. Produksi Tanaman Vol 4 (7): $538-546$

Rizqullah, H., Sitawati dan B. Guritno. 2017. Pengaruh Macam dan Cara Aplikasi Pupuk Organik terhadap Pertumbuhan dan Produksi Tanaman Jagung Manis. Produksi Tanaman Vol 5 (3): 387 - 389

Toutenburg, H. and Shalabh. 2009. Statistical Analysis of Designed Experiment. Third Edition. Springer. New York

Yousuf, M.N. S. Brahma, M. M. Kamal, S. Akter, dan M. E. K. Chowdhury. 2014. Effect of Nitrogen, phosphorus, Potassium, and Sulphur on the Growth and Seed Yield Coriander (Coriandrum sativum L.). Bangladesh Journal. Of Agricultural Reseach. Vol. 39(2): 303-309. 